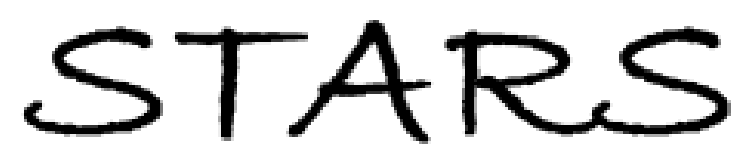

University of Central Florida

STARS

$12-16-2014$

\title{
The Return on Investment for Undergraduate Degrees in Hospitality and Tourism Management
}

Asli D. Tasci

University of Central Florida, asli.tasci@ucf.edu

Abraham Pizam

University of Central Florida, Abraham.Pizam@ucf.edu

Robertico Croes

University of Central Florida, robertico.croes@ucf.edu

Po-Ju Chen

University of Central Florida, Po-Ju.Chen@ucf.edu

Part of the Hospitality Administration and Management Commons, and the Tourism and Travel Commons

Find similar works at: https://stars.library.ucf.edu/rosenscholar

University of Central Florida Libraries http://library.ucf.edu

This Paper is brought to you for free and open access by the Rosen College of Hospitality Management at STARS. It has been accepted for inclusion in Rosen Faculty Scholarship and Creative Works by an authorized administrator of STARS. For more information, please contact STARS@ucf.edu.

\section{Original Citation}

Asli Tasci, Abraham Pizam and Robertico Croes. (2016) "The Return on Investment for Undergraduate Degrees in Hospitality and Tourism Management," Tourism Economics Fast Track, DOI 10.5367/ te.2014.0447

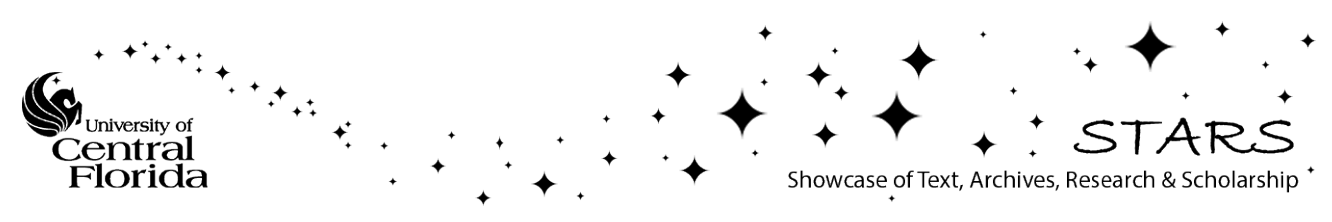




\section{Publisher's notice}

This Tourism Economics Fast Track paper has been peer-reviewed, revised and fully accepted for publication in Tourism Economics. However, this is an unedited manuscript and will undergo a rigorous editing process before its appearance in an issue of the journal. This means that this manuscript version of the paper may not conform to journal style in terms of presentation, spelling and other usages. It may also contain minor errors of typography, grammar, spelling, referencing, etc, all of which will be corrected in the processes of copy-editing and proofreading.

Tourism Economics operates a Fast Track online publication system so that papers can be published and made available almost immediately on final acceptance by the journal.

\section{Citing this article}

Each Tourism Economics Fast Track article is given a DOI. When the paper is assigned to an issue, this DOI will automatically be transferred to the article in the journal issue.

This version of the article may be cited using the DOI. Citations should include the author's or authors' name(s), the title of the article, the title of the journal followed by the words 'Fast Track', the year of Fast Track publication and the DOI. For example:

Smith, J. (2014), ‘Article title’, Tourism Economics Fast Track, DOI xxxxxxxx.

Once the paper has been published in an issue of the journal, the DOI will automatically resolve to that final version and the article can be cited in accordance with normal bibliographical conventions.

Article copyright (C) 2014 IP Publishing Ltd.

doi: 10.5367/te.2014.0447 


\title{
THE RETURN ON INVESTMENT FOR UNDERGRADUATE DEGREES IN HOSPITALITY AND TOURISM MANAGEMENT
}

Asli D. A. Tasci*

Rosen College of Hospitality Management

University of Central Florida

9907 Universal Boulevard

Orlando, FL 32819, USA

Asli.Tasci@ucf.edu

\author{
Abraham Pizam \\ Rosen College of Hospitality Management \\ University of Central Florida \\ 9907 Universal Boulevard \\ Orlando, FL 32819, USA \\ Abraham.Pizam@ucf.edu

\section{Robertico Croes} \\ Rosen College of Hospitality Management \\ University of Central Florida \\ 9907 Universal Boulevard \\ Orlando, FL 32819, USA \\ Robertico.Croes@ucf.edu

\section{Po-Ju Chen} \\ Rosen College of Hospitality Management \\ University of Central Florida \\ 9907 Universal Boulevard \\ Orlando, FL 32819, USA \\ Po-Ju.Chen@ucf.edu \\ *: Corresponding Author
}




\title{
THE RETURN ON INVESTMENT FOR UNDERGRADUATE DEGREES IN HOSPITALITY AND TOURISM MANAGEMENT
}

\begin{abstract}
Increasing concerns regarding the value of higher education in the USA have motivated several organizations to calculate the return on investment (ROI) for college education by employing diverse methodologies. This study evaluates these methodologies by using data from a survey of alumni of Rosen College of Hospitality Management at the University of Central Florida. The results reveal that the highly publicized low ROI for college education might be inaccurate, confusing and misleading for several reasons, among which is the assumption of zero income while studying, causing debt to be the total of a student's expenses. Data reveal that Rosen College graduates who work in mandatory paid internships and hold part-time jobs could be debt-free within two years if they pay $20 \%$ of their salary toward their debt. A more valid and reliable education ROI calculation method is proposed for the USA and other countries where students must pay tuition and acquire loans to cover their educational expenses.
\end{abstract}

Keywords: return on investment, ROI, education investment, hospitality and tourism, value of education, Rosen College of Hospitality Management 


\section{INTRODUCTION}

Once considered the pathway to transcend social class, the value of higher education in general and hospitality and tourism education in particular has received heightened attention recently, spawned by increasing costs of education, soaring outstanding student loans and truncated job prospects, especially in the United States. Individual benefits obtained from higher education are under intensifying scrutiny from students, parents and society at large struggling with whether the investment in higher education is worth the time and money. Some sources question the usefulness of higher education when considering the lifetime earnings of a college degree versus the costs (loan plus opportunity cost) accrued by a college graduate. One online source, Salary.com, specifically questioned the value of a hospitality management degree despite its value in the job market.

Jobs in the hospitality industry have increased significantly over time. According to the U.S. Bureau of Labor Statistics, hospitality and leisure was one of the nation's fastest growing job categories during 2000-2014, with growth prospects of 1\% annually from 2014-2022. Despite the important role of the hospitality industry as a source of jobs, there are some concerns about the economic value and the commensurate low pay associated with these jobs. For example, several news information sources, such as Career Builder, The Huffington Post, CBS Money Watch, Forbes, MyPlan.com and MSN Money, among others (Lorenz, 2008; Kristof, 2011; Kurtzleben, 2013; Smith, 2013; Doyle, 2013), have recently expressed concern over the low-paying nature of hospitality and tourism jobs. These discouraging commentaries were reinforced by a report published by Salary.com regarding the low return on investment (ROI) for a number of undergraduate degrees including hospitality management. 
The purpose of the current study was to assess and compare the return on investment (ROI) of a hospitality management undergraduate degree by employing the four ROI methods currently used by PayScale, College Reality Check and Salary.com to propose a more comprehensive and accurate method. The assessment and comparison was conducted by applying these ROI methods on data collected from alumni of the Rosen College of Hospitality Management at the University of Central Florida.

\section{THEORETICAL BACKGROUND}

\section{The Significance of College Education}

College education becomes a viable and strategic option, especially during economic downturns, to enhance knowledge, skills and employability, and occupational success and to secure a better-paying job. There is merit in such expectations because studies have confirmed the positive relationship between higher education and earnings (Ashenfelter and Rouse, 1999; Becker 1967, Card, 2001; Dwyer, McCloud and Hodson, 2012; Kane and Rouse, 1995). However, recent career- and job-related news and questioning of the value of college degrees become increasingly more salient for households and, thus, an attractive media story. Nonetheless, questioning the value of a college degree is unfounded based on studies that confirm a college degree is valued by the job market (Carnevale, Strohl \& Melton, 2009; Canon \& Gascon, 2012). The market seems to value college degrees because the proportion of those with a bachelor's degree in the labor force has increased from 28\% in 1992 to 34\% in 2008. (Carnevale et al., 2009). Despite higher tuition costs, more people enter college today than did so ten years ago. Between 2001 and 2011, undergraduate enrollment rose 32\%, from 13.7 million to 18.1 million, according to the National Center for Education Statistics. 
A college degree brings many individual benefits such as lower unemployment, better occupations, higher earnings and a better quality of life (Ashenfelter and Rouse, 1999; Becker 1967, Card, 2001; Dwyer, McCloud and Hodson, 2012; Hout, 2012; Kane and Rouse, 1995). College graduates are more likely to get a job than are their peers with a high school diploma (Canon \& Gascon, 2012). Kane and Rouse (1993) reported that workers had 5\% to 8\% more earnings for each completed additional year of college when compared with those who finished only high school (Montmarquette, Cannings, and Mahseredjian, 2002; Robst, 2007). The Hamilton Project, guided by faculty and staff from several universities, calculated estimated lifetime earnings of college graduates with different majors in the United States; the study estimated that a typical graduate with a bachelor's degree will earn \$1.19M USD over his or her lifetime, double that of a high school graduate (Jacobs, 2014). A college degree also has spillover effects in society through increased productivity, reduction in criminal behavior, and improvement in political participation and civic life (Owen \& Sawhill, 2013).

Therefore, there is a growing consensus that earning a college degree is worth the investment. A college degree is better than having no college degree, despite failure and earnings risks involved such as that the individual may not complete the degree, may not get a job, or may get a job without the expected earnings from investing in a college degree (Bound, Loevenheim \& Turner, 2009). Additionally, not all college degrees have the same market value. The study of Carnevale et al. (2009) indicates substantial variance in earnings among majors. Similarly, the research firm PayScale estimated financial returns of many different types of degrees and concluded that some degrees may even incur negative returns. Therefore, while a college degree has value, certain types of degrees or majors may have different economic values. 
However, college education comes with a bill that includes various costs for attending higher education. These include tuition, fees, personal expenditures (rent, transportation, etc.), and the opportunity cost of delaying entrance to the labor market. To cover some of these costs, individuals obtain financial support, for example, bank loans or government-supplemented student loans. Ricciardi et al. (2012) revealed that college student debt is approximately $40 \%$ of the U.S. financial burden. Increasing public concerns about student debt in the United States recently culminated in a pledge by the National Education Association (NEA, 2014): "Degrees Not Debt.” Although relevant, the reasons for and results of student debt are beyond the scope of the current paper and, thus, will not be discussed further. However, even with negative connotations, debt is viewed as a means to ensure higher education completion, develop human capital and improve career opportunities (Dwyer, McCloud and Hodson, 2012).

\section{Recent Critiques on Hospitality and Tourism Jobs}

As the economic downturn continues to take its toll around the world in the second decade of the $21^{\text {st }}$ century, the low-paying nature of hospitality and tourism jobs has resurfaced as a public concern. In the past few years, several news information sources have reflected on the low-paying nature of hospitality and tourism jobs, dating back to as early as 2008. Career Builder started in 2008 by naming some hospitality and tourism jobs as “America’s lowest paying jobs” (Lorenz, 2008). The article began with this cynical statement: "You've heard the clichés: Money doesn’t buy happiness, you should do what you love, blah, blah, blah. But, survey after survey shows that pay is the No. 1 motivating factor for work.” However, the article eventually did justice to some of these low-paying jobs by later stating, “A lower-paying, entrylevel job can help you to build up your résumé, test-drive different industries and carve a path for 
success. Consider Janice L. Fields. Fields started her career with McDonald's in 1978 as a crew member; today she's executive vice president and chief operations officer for McDonald's USA. Yes, the road to the top is often a long one and it takes hard work, but it is possible to achieve large amounts of success with a very simple start. Consider one of these jobs that could be your ticket to professional glory” (Lorenz, 2008).

Other reports were not as didactic. In 2011, The Huffington Post stated that the hospitality and tourism industry is among "the 10 lowest-paying jobs in America: What do fast food cooks, amusement park employees and farm workers have in common? They are among the lowest paying jobs in America today.” CBS Money Watch also broadcasted the same information with the headline, “10 worst-paid jobs in America,” along with salary figures and a warning attached: "Mamas don't let your babies grow up to be cashiers or food service workers. There are millions of jobs in these professions, but their average wages are paltry, amounting to less than half the pay of the average American worker” (Kristof, 2011).

The news escalated even more in the second decade of the $21^{\text {st }}$ century. In 2013, US News wrote, “The 10 lowest-paid jobs in America: Food service workers and their colleagues at bars and restaurants dominate the list of the lowest-paid professions, taking up six of the top 10 spots” (Kurtzleben, 2013). Forbes joined with “The best- and the worst-paying jobs in America: six of the 10 lowest-paying jobs are food preparation- and serving-related occupations, while three are personal care and service occupations. The only low-paying job that isn't in either of those two areas is farmworkers and laborers (No. 8)” (Smith, 2013). MyPlan.com included these jobs among the “Top 300 lowest paying jobs in America.” MSN Money also published Smith’s Forbes article and helped spread the news. About.com's Job Search site also jumped on the 
bandwagon and used the same information in their article, “Top 20 worst paid jobs” (Doyle, 2013).

All these news stories share one common denominator: they are based on the U.S. Department of Labor’s Bureau of Labor Statistics’ Occupational Employment and Wage Estimates survey data, which report salary and employment data gathered from more than one million businesses. As negative and discouraging as the news is, the majority of the reported jobs related to the hospitality and tourism industry are rather lower-level operative types of jobs such as fast food cooks or servers, dishwashers and bartender helpers. These entry-level jobs do not require hospitality and tourism education at a tertiary institution; on-site job training achieves very well the capacity building required for these lines of work. However, hospitality and tourism education students are also involved in some of these jobs early on in their careers and move to higher-level jobs as they gain knowledge and experience. In fact, it is a common recommendation for a hospitality and tourism manager to go through these lower-level jobs to understand fully the diverse aspects involved in managing a facility.

The news about these operative-level jobs has now been left in the shadows due to a new line of criticism about the hospitality and tourism industry and tertiary education institutions offering hospitality and tourism related degrees: the relatively low return on investment (ROI) for hospitality and tourism college education. With a heightened level of attention on financial returns in light of the economic downturn, some education and job-related sources have been providing college-level ROI information for student candidates, families and their financial supporters to benchmark when making choices regarding college level education. Studies confirmed expected earnings are essential in choosing a college major (Montmarquette, 
Cannings, and Mahseredjian, 2002; Robst, 2007); however, the methodology used to calculate the ROI on education becomes very critical so as not to confuse or mislead potential users.

\section{ROI for Assessing Value or Productivity of an Investment Decision}

“The ROI Methodology ${ }^{\mathrm{TM}}$ was developed by Dr. Jack J. Phillips in the 1970s, refined through application and use in the 1980s, and implemented globally during the 1990s” (ROI Institute, 2013). ROI is one of the tools created to solve the long-term debates between finance and marketing professionals. Finance professionals’ concerns about increasing marketing expenses for intangible returns, such as consumer satisfaction and loyalty, lead to increasing pressure on marketing professionals to provide evidence of the value of their marketing efforts in measurable terms (Farris, Bendle, Pfeifer, and Reibstein, 2010; Rust et al., 2004; Schultz, 2002a, 2002b, 2006; Sheth and Sisodia, 1995a, 1995b; Srivastava et al., 1999).

Defined as a rate or percent justifying the value of one investment over another, ROI provides a measure of marketing effectiveness and relative contribution of different marketing applications to return on investment (Lenskold, 2002, 2004; Klein and Swartzendruber, 2003; Pettit, 2005; Schultz, 2002a). Today, ROI is a productivity metric used to measure and evaluate the productivity and efficiency of management activities such as human resource training, IT adoption, quality programs, consumer loyalty programs, brand development and marketing communications (Dekleva, 2005 Schultz, 2002a, 2002b).

The most commonly accepted calculation of ROI involves an input-output perspective that generates a ratio of inputs and outputs such as sales, profits, market share and cash flow (Rust et al., 2004 Schultz, 2002b). However, there has been a debate about which variables should be included in both inputs and outputs to comprehensively capture the productivity of an 
activity, especially those complex activities including diverse inputs and outputs (e.g., Davis and Smith, 1998; Dias and Ryals, 2002; Reynolds and Phillips, 2005; Schultz, 2002a, 2002b).

Several qualitatively and quantitatively defined measures have been suggested for inclusion in comprehensive ROI calculation, especially for complex decision contexts. Some of these measures can also be applicable to measuring and evaluating the ROI of education. These include the amount of investment, the results of the investment, the period of measurement of long-term outputs rather than the prejudicial measure of short-term financial impact, the gain of the benefactors (i.e., those who benefit from the product or service), and environmental factors such as, the general economy, health issues, etc. (e.g., Davis and Smith, 1998; Dias and Ryals, 2002; Reynolds and Phillips, 2005 Schultz, 2002a, 2002b).

In addition to measures that are included in ROI calculations, the ROI formula also varies among different users of ROI as an indicator of productivity. ROI can be calculated as a percent or as a ratio of the cost of investment as stated with the formulas below:

ROI (\%) $=$ (Net profit $/$ Investment $) \times 100$

ROI $=$ (gain from investment - cost of investment $) /$ cost of investment

\section{ROI for Assessing the Value or Productivity of College Education}

The sources calculating ROI for education not only use different ROI formulas but also different assumptions and different data. Table 1 summarizes the information on the most popular education ROI calculator sites. PayScale (http://www.payscale.com/college-roi/) and College Reality Check (http://collegerealitycheck.com/en/about/) are the two sources calculating ROI at the university level. These are the most visible sources reflected on media channels such as Bloomberg BusinessWeek and the New York Times (see Lavelle, 2012a, 2012b; Stainburn, 2013). PayScale is one of the most referenced sources of benchmark information for students and 
their families seeking to make intelligent education decisions. It calculates 12 different ROIs at the college level with different assumptions, incorporating financial aid, family situation and onor off-campus residency. Another education ROI reporting source is College Reality Check, “produced by The Chronicle of Higher Education with support from the Bill \& Melinda Gates Foundation...to share facts and figures that students, parents and counselors should weigh in making decisions about college” (College Reality Check, 2014). This source also uses earnings figures from PayScale to calculate the ROI of investment in education. Similar strengths and weaknesses may apply to both PayScale and College Reality Check. A similar website called Bankrate provides college-level ROI, but differs in that it provides ROI in terms of years needed to repay an investment in education with $10 \%$ of a median salary used to pay the cost of education.

*** Insert Table 1 About Here***

Salary.com’s recent ROI calculations have been most destructive to the value of hospitality and tourism college educations. The site listed some hospitality and tourism degrees as \#4 on a list of eight college degrees with the worst return on investment (Dugan, 2013). Median salaries for the three jobs listed (meeting/event planner, hotel resident manager and catering manager) were $\$ 55 \mathrm{~K}$, \$65K and \$42K, respectively. With 30-year earnings of \$3.3M, $\$ 3.8 \mathrm{M}$ and $\$ 2.5 \mathrm{M}$, only a hotel resident manager reaches $100 \%$ ROI when the degree is from a public college. Thus, Dugan (2013) poses wakeup call for those wizards behind the curtains who are “...working like a dog to make it all happen while everyone else is enjoying the fruits of your labor. Unfortunately, there isn’t always a lot of financial benefit after earning your degree.” Education Sector (2013) views such education ROI sources with skepticism, sharing the concern that “...prospective students will place too much emphasis on the economic returns of a 
college degree... a college degree serves multiple purposes, many of which are difficult to value. A college education is also what economists often refer to as an 'experience good,' meaning its quality and value can't be discerned in advance. It's only after you have experienced the product (obtained the education) that you can place a true value on it (and arguably not even then, since you have little to compare it to).” Thus, Education Sector recommends use of student satisfaction surveys by uniform collection and reports of results of student satisfaction surveys to provide prospective candidates information and insights about students' actual experiences in class and on campus, the value they place on their education, and whether they believe their education was helpful in acquiring their job. Bruner (2013) pinpoints the effect of increasing interest rates of student loans and student debt as triggers "of finger-pointing: claims that universities charge too much; employers aren't making jobs available for graduates; the government isn't doing anything to help; the students didn’t know what they were getting into; and bankers are heartless in throwing hapless borrowers into bankruptcy." Considering that ROI calculations are based on large-sample findings and generalizations, he also recommends the inclusion of other important variables in calculating ROI of investment in education, including "greater career flexibility ... higher quality of life ... higher prospects of social mobility ... growth in wisdom...(and) reduction in risk of unemployment” (Bruner, 2013).

Although these sites may provide an overall understanding to student candidates and their families for intelligent decision-making, their information may also mislead individuals and do disservice to some industries, such as the hospitality and tourism industry, due to several disadvantages listed in Table 2 that can be summarized as:

1) Their methodology is not fully transparent; some details about their assumptions are not revealed, hindering complete understanding of their results. This also obstructs replicability of their methodology for checks on reliability and validity. 
2) They use data of different natures, some from national organizations and some from their own sources provided voluntarily by certain types of individuals who are not necessarily representative of the entire population, the specific universities or majors.

3) They use different ROI calculation methods and metrics, some revealing ROI as dollars, some as years and some as rate of return. This impedes crosschecks among different sources and methods for validity.

4) Those sources that calculate ROI as additional dollars as opposed to early career after high school assume that every high school graduate has the opportunity and capability of securing a job with an average salary of $\$ 30,000$ annually.

5) Their ROI calculation methods factor in inflation on salaries but overlook the associated promotional increments; hence, ROI on education is underestimated.

6) Those sources reporting college-level ROI also have issues of reliability and validity because there is a wide range of differences among different majors in terms of the variety of opportunities to excel, the variances in promotion opportunities, promotion speed and salary increases. These variations may exist even among the same majors in different locations.

7) All ROI calculations overlook the additional income that is earned during college education and consider the entire education cost as an outstanding debt at the end of the education. Many majors such as hospitality and tourism provide additional income opportunities through mandatory paid internships. In addition, many hospitality and tourism programs provide their students many opportunities to earn additional income through part-time jobs in the local hospitality and tourism industry.

8) All ROI calculations reflect only dollar inputs and outputs; other qualitative non-financial outputs, such as student satisfaction, have been totally ignored thus far.

\section{*** Insert Table 2 About Here***}

These weaknesses may not be as clear even to researchers who do not pay specific attention to this subject matter, let alone unquestioning laypersons without scientific inquisition skills. Because the ROI discussion seems to be escalating and putting more scrutiny on the value of college education, especially for hospitality and tourism education, it is time that these different ROI methods are compared using data from a specific major rather than college-wide data. The recent attention to ROI of college education has been intense in the United States due to the high cost of education and the heavy burden of interest-bearing student loans. Similar concerns may exist in other countries where college education is neither free nor heavily subsidized by the state. Thus, a sound education ROI methodology can be beneficial for all 
hospitality and tourism educational institutions in the United States and other countries where students must pay for their own education.

The ROI on college education may depend on the locality of the educational institution in the context of hospitality and tourism education. First, in the United States, state-owned universities such as the University of Central Florida have relatively lower tuition rates than private universities, the proportion being one third or sometimes even one fourth. Second, an educational institution in a tourism-dependent locality versus another in a remote area may actually reveal rather different returns on investment. The tourism development level at the destination defines the types of opportunities, promotions and salary levels that not only the graduates but also current students may receive while pursuing their education. Rosen College of Hospitality Management provides one such case, where students have additional earnings during their period of study through mandatory paid internships as well as part-time jobs in the industry.

The Rosen College of Hospitality Management was first established in 1983 as a department within the College of Business Administration at the University of Central Florida, now the second largest university in the United States. In 2000, it was elevated to the status of an autonomous school and renamed the Rosen School of Hospitality Management following an \$18.2 million donation by hotelier Harris Rosen in Orlando (RCHM, 2014). In 2004, the School opened a Universal Blvd. campus and was renamed the Rosen College of Hospitality Management. As a \$28.1 million state-of-the-art project, the new Rosen College campus is the largest, most advanced facility ever built for hospitality management education in the United States (RCHM, 2014).

Every year, Rosen College graduates approximately 750 undergraduate students with degrees in hospitality management, event management, and restaurant and foodservice 
management. Alumni and students reap the benefits of Rosen College's location in the premier learning laboratory for the hospitality and tourism industry: Orlando, Florida. With three major theme parks, Walt Disney World Resort ${ }^{\circledR}$, Sea World ${ }^{\circledR}$ Adventure Park and Universal Orlando Resort ${ }^{\circledR}$, Orlando is a global theme park destination brand receiving over 50 million visitors annually (VisitOrlando, 2013). Rosen College is minutes away from top hotels and restaurants on International Drive, the Orange County Convention Center and the Orlando International Airport, so students have access to plenty of job opportunities within a reasonable commute. Having close ties, relations and partnerships with the local industry, Rosen College offers ample work opportunities for their students during their period of study and upon graduation (Pizam, Okumus, and Hutchinson, 2013). A survey conducted among internship students revealed that in terms of job opportunities, students rate both Orlando and Rosen College an average of 8.0 on a 10-point Likert Scale. This is because students have many opportunities for additional earnings during their education not only through the mandatory paid internship program of 39-42 weeks but also through paid part-time jobs. A study conducted on 2676 students who were on internship in 2012 revealed that earnings from mandatory paid internship contributed 17.1 million USD in total economic impact to Orlando (Croes and Hara, 2013).

\section{COMPARING DIFFERENT METHODS OF ROI WITH DATA FROM ROSEN COLLEGE ALUMNI}

\section{Methods}

To compare the differential ROI results obtained through employing the methods of PayScale, College Reality Check, Salary.com and Bankrate, an online survey was conducted on the alumni of the Rosen College of Hospitality Management at the University of Central Florida. 
For anonymity and confidentiality purposes, contact with respondents was achieved through collaboration with the Rosen College of Hospitality Management Alumni Chapter of the UCF Alumni Association. The survey team prepared the surveys and e-mail messages and the alumni chapter delivered them to the alumni. A short and concise survey was designed online using Qualtrics.

The survey included basic sociodemographic questions including age, gender, marital status, residence, race/ethnicity, income (salary), area of study, employment status after graduation, current workplace and sector, graduation year and current job title. The survey also included more qualitative measures of the value of education including 7-point Likert-type ratings of skills gained at Rosen College, satisfaction with the education, loyalty to Rosen College and current job satisfaction. Initial contact was followed by two reminders sent to 5,439 unique e-mail addresses in the contact list, which resulted in 591 surveys, an 11\% response rate.

\section{Results}

Respondents' mean age was 31.25 years; the total was dominated by females (66\%) and whites (80.5\%) who were mostly single (48.8\%) or married (38.2\%). A majority of the respondents work and live in Florida (approximately 70\%). Most of the respondents majored in hospitality management (78.4\%), followed by event management (19.8\%), and restaurant and foodservice (1.7\%). As far as employment status, the majority of respondents (87.9 \%) were employed immediately after graduation, $6.5 \%$ are currently pursuing higher degrees, $3.5 \%$ are taking some time off and the rest are volunteering, serving in the military or building a family. Those who were employed were mostly full-time employees (88.3\%) in the hospitality and 
tourism industry (65\%), specifically, in hotels (33.8\%), restaurants (14.5\%), events (14.2\%), and theme parks or attractions (12.4\%).

As displayed in Table 3, graduation years ranged from 1986 to 2014, with an average of 4.2 years for completion of education. The total cost of education over those years ranged from $\$ 2000$ (for those using scholarships) to $\$ 355,000$ with a mean of $\$ 44,257$ and a median of $\$ 35,000$. With an average of 10 years of work experience in the field, the respondents’ mean and median annual salary were $\$ 53,291$ and $\$ 43,000$, respectively. Some respondents reported rather low salaries because they made some other life choices after graduation such as taking time off or continuing education. The study also measured alumni satisfaction with their job and education. About 75\% reported to be satisfied or enthusiastic about their current position and 73\% said their education was worth every penny.

***Insert Table 3 About Here***

Using the ROI formulas and calculation assumptions of PayScale, College Reality Check, Bankrate and Salary.com, the ROI for the current sample was calculated. Additional assumptions were made due to the lack of information from those sources. Table 4 displays the formulas and assumptions based on the information from these sources, the additional assumptions due to the lack of information and the resultant ROIs. As observed in the table, due to different ROI methods used by the sources, ROIs are expressed either as a dollar amount, a year, or as a rate of return. Three ROIs were calculated at 3 levels: (1) education cost with no student loans or no interest on the cost for those who used their own sources to pay for education expenses; (2) education cost with student loans and interest for those who borrowed money to pay for their education; and (3) education cost with student loans and interest, with loans being amortized 
after 50 months for those who borrowed money to pay for their education and started repaying the loans immediately after graduation.

\section{***Insert Table 4 About Here***}

The ROI with the PayScale method is a dollar amount, more specifically, additional dollars that a person would have to pay to pursue college education instead of an early career after high school. According to this ROI method, within 20 years after graduation, those alumni with student loans would be at a loss of $\$ 18 \mathrm{~K}$, which would turn into a gain of $\$ 33 \mathrm{~K}$ if loans were amortized after 50 months. Those without student loans would gain an additional $\$ 77 \mathrm{~K}$ due to their college degree. College Reality Check uses the same method with half the period: 10 years. With the period shortened to half, with or without loans, Rosen College alumni would be at loss of over $\$ 50 \mathrm{~K}$ within 10 years of their graduation. Both of these ROI methodologies factor in the loss of potential after-high school salaries due to college education, which lowers the additional earnings due to college education. From the viewpoint of these two methods, the value of college education is questionable.

On the other hand, Salary.com's ROI method is similar to the conventional ROI method, calculating the rate of return on investment over a 30-year period after graduation rather than gains in dollars or years to pay back. With this method, return with loans is approximately 9\%, which becomes $24 \%$ when loans are amortized, while return without loans is approximately 72\%. This means that student loans reduce the rate of return by eight times without amortization and by approximately three times with amortization.

Finally, Bankrate’s ROI method calculates the number of years required to pay back the cost of education if $10 \%$ of the salary after graduation was used to pay back the education cost. With this ROI method, alumni with student loans break even in approximately 13 years and 
those without student loans do so in about half that time. However, with this methodology, student loans increase the payback time by approximately $50 \%$.

As evidenced from the comparative numbers, the longer the period used in the ROI calculation method, the higher the return on investment. With the shortest period, College Reality Check’s method reveals the worst return on investment; with the highest period, Salary.com's method reveals the best return on investment, especially for those without student loans. Overall, however, exposing all of these figures to a potential candidate can create some level of confusion. Thus, the desired outcome in terms of providing a benchmark for intelligent decision-making may not be achieved.

\section{Rosen College ROI Method}

ROI in years seems to be a more standard unit of analysis; the meanings of currencies change from country to country, but the meaning of years is uniform worldwide. Also, ROI expressed in years also allows adjustment of the calculation based on payment amounts that an individual is willing to make per month. Depending on household income, a graduate can pay up to $30 \%$ of his or her salary toward student loans, paying them off earlier than usual. Thus, Bankrate's ROI method is the suggested method for a more standardized measure of ROI. However, the interest rate needs to be adjusted to $6.8 \%$, which seems to be a more common rate for student loans. In addition, calculating ROI after student loan amortization is suggested as a more valid measure.

Hospitality and tourism graduates, in general, have a high probability of securing jobs due to diverse job opportunities in the industry. Some colleges in tourist-oriented areas, such as Rosen College, offer even more-lucrative job markets for their students. Therefore, graduates 
may start paying back their loans immediately after graduation. In this study, the payback time was assumed to start four years plus one month after graduating in four years, which is suggested as a more valid estimate of the value of education. The rationale of this suggestion is that paying the cost of education back can start as soon as a job is secured, an event that can even be before graduation in cases where students have opportunities to do so while still in college. As previously mentioned, Rosen College students have many opportunities for part-time and fulltime jobs in Orlando.

Based on these additional assumptions, for example, a loan of \$2,000 would accumulate $\$ 2,470.30$ in principal and interest after 49 months; a loan of $\$ 10,000$ would become $\$ 12,351.49$; a loan of $\$ 20,000$ would accumulate to $\$ 24,702.98$, etc. The median annual income earnings of $\$ 43,000$ in this sample equals $\$ 3,583.33$ in monthly income earnings. If the graduate pays $10 \%$ of his or her monthly income on a loan of $\$ 2,000$, the loan will be paid off within six months; if the graduate pays $20 \%$ of his or her monthly income, the loan will be paid off in three months. Similarly, if the loan amount is $\$ 10,000$ and monthly payments are capped at $10 \%$, the graduate would pay off the loan in 3.2 years, while a $20 \%$ monthly cap would imply a payoff in 1.5 years. If the loan amount were $\$ 20,000$ at a $10 \%$ monthly cap, the payoff time would be 7.3 years, while a 20\% monthly cap implies a payoff in 3.2 years.

Table 5 displays the calculations based on this modified methodology. Based on a median student debt of $\$ 35,000$ and a median salary of $\$ 43,000$ in the current study with a monthly payment cap of $10 \%$ ( $\$ 358.33$ per month), the loan would be paid off in 17 years. If the graduate decides to pay $20 \%$ of the salary toward student loans (\$716.67 per month), then the loan would be paid off in 6.2 years. If the monthly cap is increased to $30 \%(\$ 1,075.00)$, then the payback time reduces to 3.8 years. 
As was mentioned before, Rosen College students also have an opportunity to earn additional income through mandatory paid internships and additional part-time jobs. A study conducted among internship students revealed that Rosen College students earn a median of $\$ 11,000$ from internships and $\$ 13,000$ from part-time jobs during their four-year study. These numbers were also used to calculate ROI by subtracting the additional income from education cost to define the outstanding debt that needs to be returned to personal funds, parents or other loaners at the end of the college education. If students use their internship earnings $(\$ 11,000)$ toward paying some of the costs of their education, the debt can be reduced to $\$ 24,000$ ( $\$ 35,000$ $\$ 11,000)$. Thus, the payback time for students with different education finance situations and different payment plans $(10 \%, 20 \%$ or $30 \%$ of salary) ranges from 9.3 years to 1.3 years. If students use their income from both internship and part-time jobs $(\$ 13,000)$ toward paying their education costs, the outstanding education debt can be as low as $\$ 11,000[\$ 35,000$ $(\$ 11,000+\$ 13,000)]$, with a payback time ranging from 3.6 years to 6.5 months.

Readers should be cautioned that not every student would be a conscientious money manager who would spend his/her additional earnings toward paying their educational expenses to reduce their debt. Readers should also keep in mind that these calculations reflect an average Rosen College alumni and not diverse types of alumni with different situations based on individual choices such as taking time off or continuing education.

\section{LIMITATIONS AND FUTURE RESEARCH SUGGESTIONS}

ROI measures utilized in one-fits-all models seem to be too simple to cover all relevant performance measures of a complex life decision such as investing in education in a field. As 
also suggested by Bruner (2013), a model of education productivity must go beyond these simple measures to include other strategic measures that are inherently pertinent to the holistic life satisfaction of an individual. The significance of a measurement metric to evaluate the productivity of investment in education in a field will depend on its ability to combine the financial perspective with non-financial perspectives. Important inputs and outputs need to be factored in to determine a holistic ROI of investment in college education. Intangible outputs or returns that need to be considered include opportunity for personal and professional growth, becoming a multidimensional individual, having a high level of social interaction, developing social networks, ease of entry into the job market, job satisfaction and even life satisfaction in relation to jobs. Some of these intangible returns may also have side returns. Developing a social network and having a high level of social interaction in daily life, for example, may result in a healthier physical and psychological state for an individual. "A network of supportive relationships contributes to psychological well-being ... (through a) sense of belonging ... increased sense of self-worth ... feeling of security” (Mayo Clinic, 2012).

However, defining such a comprehensive ROI metric may pose methodological and operational challenges. A significant challenge of measurement is how to quantify both financial and non-financial inputs as well as outputs. Another major challenge comes from individual differences. The ROI of education would be highly variable depending on personal factors affecting the cost of education and salary. For example, a "party animal" type of student with excessive spending tendencies can have a very low ROI on his or her education, while a conservative type of student with a tendency to save has the opposite ROI case. Similarly, a graduate with high aspirations and ambition may pursue and acquire high-paying jobs as opposed to another, more passive and unambitious individual. 
As was suggested by Education Sector (2013), it is the duty of universities, individual colleges and majors to establish a system to generate reliable and valid information about the value of their education. Perhaps all universities need to adopt a uniform ROI calculation system for the benefit of their own institutions and alumni. Such a system would be especially strong if it included both graduates who take jobs elsewhere and those who are self-employed in the calculation. The benefits that come with the reputation of a well-known university do not apply only in the education sector; they spill over to other sectors of the economy and society in the areas of investment, immigration and community development, as well as visitation and economic development. Thus, an investment in developing such a system may be profitable for all stakeholders.

Fair and accurate calculations of the ROI of hospitality and tourism education is important not only for educational institutions and students in the United States but also for other countries where hospitality and tourism is an important industry for the social and economic well-being of the society. Current sources publishing education ROI information overlook the macro level contribution of hospitality and tourism for the social and economic well-being of a society. The United Nations and its agencies consider hospitality and tourism an important tool for accomplishing the Millennium Development Goals that envision the greater good of world society. For a fair assessment of education for this industry, the ROI calculation method proposed in the current study can be used by other institutions around the world, where students pay for their educations and need loans to pay their expenses. Ultimately, such a fair, accurate and reliable calculation of ROI on hospitality and tourism education would help generate a positive attitude toward hospitality and tourism education globally. 


\section{REFERENCES}

Becker, G. S., \& Chiswick, B. R. (1966). Education and the Distribution of Earnings. The American Economic Review, 358-369.

Bound, J., Loevenheim, M. \& Turner, S. (2009). Why have college completion rates declined? An analysis of changing student preparation and collegiate resources. National Bureau of Economic Research Working Paper 15566/

Bruner, B. (2012). The ROI on One’s Own Higher Education. DARDEN. https://blogs.darden.virginia.edu/deansblog/2012/10/the-roi-on-ones-own-higher-education/

Canon, M. \& Gascon, D. (2012). College Degrees: Why aren’t more people making the investment? The Regional Economist.

Card, D. (2001). Estimating the return to schooling: Progress on some persistent econometric problems. Econometrica, 69(5), 1127-1160.

Carnevale, A., Strohl, J., and Melton, M. (2009). What's It Worth? The Economic Value of College Majors. Center on Education and the Workforce of the Georgetown University, http://www9.georgetown.edu/grad/gppi/hpi/cew/pdfs/whatsitworth-select.pdf.

Croes, R. and Hara, T. (2013). Annual Impact of Paid Internship Programs at a Hospitality Management Program - a Case of the largest hospitality management program in North America. Journal of Tourism Economics, Policy and Hospitality Management 1(1), 1-13.

Davis, S. M., \& Smith, J. (1998). Do you know your ROBI? Management Review, 87(9), 55-58.

Dekleva, S. (2005). Justifying Investments in IT. Journal of Information Technology Management, 16(3): 1-8. 
Dias, S., \& Ryals, L. (2002). Options theory and options thinking in valuing returns on brand investment and brand extensions. Journal of Product \& Brand Management, 11(2), 115128.

Doyle. A. (2013). Top 25 Worst Paid Jobs. About.com- Job Searching. Last viewed on 7/29/2014 on the WWW: http://jobsearch.about.com/od/jobs/a/worst-paying-jobs.htm

Dugan. D. (2013). 8 College Degrees with the Worst Return on Investment. Salary.com http://www.salary.com/8-college-degrees-with-the-worst-return-on-investment/slide/2/

Dwyer, R. E., McCloud, L., \& Hodson, R. (2012). Debt and graduation from American universities. Social Forces, 90(4), 1133-1155.

EducationSector (2013) Degrees of Value: Evaluating the Return on the College Investment. http://www.educationsector.org/publications/degrees-value-evaluating-return-collegeinvestment

Farris, Paul W.; Neil T. Bendle; Phillip E. Pfeifer; David J. Reibstein (2010). Marketing Metrics: The Definitive Guide to Measuring Marketing Performance. Pearson Prentice Hall Hout, M. (2012). Social and economic returns to college education in the United States. Annual Review of Sociology, 38, 379-400.

Huffingtonpost. (2011). The 10 Lowest Paying Jobs In America: BLS. Last viewed on 7/29/2014 on the WWW: http://www.huffingtonpost.com/2011/11/08/lowest-paying-jobs-inamerica_n_1082017.html

Jacobs, P. (2014). The College majors with the biggest lifetime earnings. Business Insider. Last viewed on 11/20/2014 on the WWW: http://www.businessinsider.com.au/college-majorsbiggest-lifetime-earnings-2014-9 
Kahn, C. (2013). What is the ROI of your college degree? Bankrate.com. http://www.bankrate.com/finance/college-finance/roi-college-degree.aspx

Kane, T. J., \& Rouse, C. E. (1993). Labor market returns to two-and four-year colleges: is a credit a credit and do degrees matter? (No. w4268). National Bureau of Economic Research.

Kane, T. J., \& Rouse, C. E. (1995). Labor-market returns to two-and four-year college. American Economic Review, 85(3), 600-614.

Klein A. \& Swartzendruber, T. (2003). A user’s guide to marketing ROI. Marketing Health Services, 23(3), 33-36.

Kristof, K. (2011). 10 Worst-Paid Jobs in America. CBS Money Watch. Last viewed on 7/29/2014 on the WWW: http://www.cbsnews.com/8301-505144_162-36944604/10worst-paid-jobs-in-america/

Kurzleben, D. (2013). The 10 Lowest-Paid Jobs in America. US News. Last viewed on 7/29/2014 on the WWW: http://www.usnews.com/news/articles/2013/03/29/the-10lowest-paid-jobs-in-america

Lavelle, L. (2012a). Measuring College ROI. BloombergBusinessweek. http://www.businessweek.com/articles/2012-04-09/measuring-college-roi

Lavelle, L. (2012b) College ROI: What We Found. BloombergBusinessweek. http://www.businessweek.com/articles/2012-04-09/college-roi-what-we-found

Lenskold, J. D. (2002). Marketing ROI: playing to win. Marketing Management, 11(3), 30-34.

Lenskold, J. D. (2004). Customer centric marketing ROI: the right measure for marketing profitability. Marketing Management, 13(1), 26-31. 
Lorenz, K. (2008). America's Lowest Paying Jobs. Career Builder. Last viewed on 5/29/2014 on the WWW: http://www.careerbuilder.com/Article/CB-872-Changing-Jobs-AmericasLowest-Paying-Jobs/

Mayo Clinic. (2012). Social support: Tap this tool to beat stress. Last viewed on 6/12/2014 on the WWW: http://www.mayoclinic.org/healthy-living/stress-management/indepth/social-support/art-20044445

Montmarquette, C., Cannings, K., \& Mahseredjian, S. (2002). How do young people choose college majors? Economics of Education Review, 21(6), 543-556.

MyPlan. (2011). Top Ten Lists / Lowest Paying Jobs. Last viewed on 7/29/2014 on the WWW: http://www.myplan.com/careers/top-ten/lowest-paying.php

National Education Association (NEA). (2014). Degrees not Debt. Last viewed on 6/12/2014 on the WWW: http://www.nea.org/degreesnotdebt.

Owen, S. and Sawhill, I. (2013). Should every one go to College? Brookings, Washington DC.

PayScale. (2014). Majors That Pay You Back. http://www.payscale.com/college-salary-report2014/majors-that-pay-you-back

Pettit, R. (2005). A new horizon for marketing accountability. Marketing Research Review, March, 1-5.

Pizam, A. Okumus, F. \& Hutchinson. J. (2013). Forming a long-term industry-university partnership: The case of Rosen College of Hospitality Management. Worldwide Hospitality and Tourism Themes, 5(3), 244-254.

Reynolds, T. J., \& Phillips, C. B. (2005). In search of true brand equity metrics: all market share ain’t created equal. Journal of Advertising Research, 45(2), 171-186. 
Rosen College of Hospitality Management (RCHM). (2014). Rosen College of Hospitality Management Fact Sheet. Last viewed on 6/12/2014 on the WWW: http://hospitality.ucf.edu/about-us/press-room/fact-sheet/

ROI Institute. (2013). About the ROI Institute. Last viewed on 7/29/2014 on the WWW: http://www.roiinstitute.net/about/

Robst, J. (2007). Education and job match: The relatedness of college major and work. Economics of Education Review, 26(4), 397-407.

Rust, R. T., Ambler, T., Carpenter, G. S., Kumar, V., \& Srivastava, R. K. (2004). Measuring marketing productivity: current knowledge and future directions. Journal of Marketing, 68(1), 76-89.

Schultz, D. E. (2002a). Measuring return on brand communication. International Journal of Medical Marketing, 2(4), 349-358.

Schultz, D. E. (2002b). Mastering brand metrics: the trick is to ask right questions. Marketing Management, 11(3), 8-9.

Schultz, D. E. (2006). Measuring up: brand metrics need an overhaul. Marketing Management, 15(2), 10-11.

Sheth, J. N., \& Sisodia, R. S. (1995a). Feeling the heat. Marketing Management, 4(2), 8.

Sheth, J. N., \& Sisodia, R. S. (1995b). Feeling the heat - part 2. Marketing Management, 4(3), 19.

Smith, J. (2013). The Best- And Worst-Paying Jobs In America. Forbes. Last viewed on 7/29/2014 on the WWW: $\quad$ http://www.forbes.com/sites/jacquelynsmith/2013/05/13/the-best-and-worstpaying-jobs-in-america-2/

Smith J. (of Forbes). (2014). The worst-paying jobs in America. MSN Money. Last viewed on 7/29/2014 on the WWW: http://money.msn.com/gen-x/the-worst-paying-jobs-in-america 
Srivastava, R. K., Shervani, T., \& Fahey, L. (1999). Marketing, business processes and shareholder value: an organizationally embedded view of marketing activities and the discipline of marketing. Journal of Marketing, 63(Special Issue), 168-179.

Stainburn, S. (2013). Following the Money - Calculating the Net Worth of a College Degree http://www.nytimes.com/2013/08/04/education/edlife/calculating-the-net-worth-of-acollege-degree.html?pagewanted=all\&_r=0

VisitOrlando. (2013). Orlando Visitor Volumes | Visit Orlando Information \& Research. Last viewed on 6/12/2014 on the WWW: http://corporate.visitorlando.com/research-andstatistics/orlando-visitor-statistics/visitor-volumes/ 


\section{TABLES}

Table 1. The sources calculating ROI on investment in education and their data, assumptions and ROI formula

\begin{tabular}{|c|c|c|}
\hline Source & Data & ROI calculation \\
\hline PayScale & $\begin{array}{l}\text { - Cost: tuition and fees, room and board, books and supplies as the total cost of graduating in 4,5 and } 6 \text { years } \\
\text { - Weighted Total Cost for a Graduate in 2013: average cost based on the number of years it actually takes students to } \\
\text { graduate by utilizing the percent of graduates who graduate in 4, 5, or } 6 \text { years (as reported by IPEDS) } \\
\text { - Net Cost: the difference between Total Cost and the Average Amount of Grant Aid } \\
\text { - Weighted Net Cost for a Graduate in 2013: the average cost calculated utilizing a weighted average of the net cost } \\
\text { paid by those who graduate in 4, } 5 \text { and } 6 \text { years } \\
\text { - Total Cash Compensation (TCC): TCC combines base annual salary or hourly wage, bonuses, profit sharing, tips, } \\
\text { commissions, and other forms of cash earnings, as applicable. } \\
\text { - Median Pay: The median pay is the national median (50th percentile) annual total cash compensation } \\
\text { - } 20 \text { Year Median Pay for a } 2013 \text { Bachelor's Graduate: Using PayScale's database, the expected } 20 \text { year median pay } \\
\text { for a bachelor's graduate of } 2013 \text { from a specific school by summing up the median pay for bachelor graduates who } \\
\text { graduate between } 1994 \text { and } 2013 \text { from that school } \\
\text { - Weighted } 24-26 \text { Year Median Pay for a } 2013 \text { High School Graduate: the weighted average median pay for a high } \\
\text { school graduate by utilizing a weighted average of the median pay for those who graduate between } 2013 \text { and 1990, } \\
1989 \text { and } 19888 \text { (24, } 25 \text { and } 26 \text { years of earnings post high school) }\end{array}$ & $\begin{array}{l}\text { - ROI as Dollars } \\
\text { - Time frame=20 years } \\
\text { - The wage inflation between } 1993 \text { and } 2012 \text { (20 years) reported } \\
\text { by the SSA = 3.3\% } \\
\text { - High school graduate median pay is not reported } \\
\text { - Student loan interest rate is not reported } \\
\text { - ROI=The 20-year return on investment is defined as what } \\
\text { you've earned minus both the cost of college (tuition, room } \\
\text { and board, etc.) and what you would have earned as a high } \\
\text { school graduate. } \\
\text { - ROI [(20-Year Return on Investment (2013 Dollars)] = } \\
\text { Earnings Differential (the difference between the 20 Year } \\
\text { Median Pay for a } 2013 \text { Bachelor's Graduate and Weighted 24- } \\
26 \text { Year Median Pay for a High School)] -[Weighted Total } \\
\text { Cost for a Graduate in } 2013 \text { or the Weighted Net Cost for a } \\
\text { Graduate in } 2013 \text { (for those who get financial aid) }\end{array}$ \\
\hline College Reality & $\begin{array}{l}\text { - Cost: tuition, fees, books and supplies, and the weighted average of room and board and other expenses } \\
\text { - Data from 3,578 degree-granting institutions in the United States (excluding territories) that reported a first-time, } \\
\text { full-time undergraduate degree-seeking cohort, have at least } 100 \text { undergraduate students, and awarded } \\
\text { undergraduate degrees during the 2010-11 academic year } \\
\text { - Data on colleges' average net price come from the National Center for Education Statistics' Integrated } \\
\text { Postsecondary Education System (Ipeds) } \\
\text { - Estimated debt repayment calculated using median debt at graduation and assuming a } 6.8 \% \text { interest rate calculated } \\
\text { over } 10 \text { years. Data for median debt at graduation are collected from the U.S. Department of Education’s National } \\
\text { Student Loan Data System (NSLDS) by the White House’s College Scorecard } \\
\text { - Average early career income data are collected by PayScale }\end{array}$ & $\begin{array}{l}\text { - ROI as Dollars } \\
\text { - Time frame = } 10 \text { years } \\
\text { - The interest on median debt (loans) }=6.8 \% \\
\text { - } \text { Early career earnings is not reported } \\
\text { - Salary interest rate per year to account for inflation and cost of } \\
\text { living is not reported } \\
\text { - ROI = Median earnings over } 10 \text { years - (Average net price } \\
\text { (cost - financial aid) + Early-career earnings over } 10 \text { years) }\end{array}$ \\
\hline Salary.com & $\begin{array}{l}\text { - Cost: tuition, room and board, and books, and did not factor in scholarships or grants } \\
\text { - Used current Salary.com figures on salary } \\
\text { - Using data from a recent College Board study, } \$ 37,343 \text { as an average cost of a four-year public liberal arts degree, } \\
\text { and a figure of } \$ 121,930 \text { for degrees earned at four-year private colleges. } \\
\text { - The median cash compensation over the course of } 30 \text { years of typical jobs requiring that degree using Salary.com } \\
\text { data. }\end{array}$ & $\begin{array}{l}\text { - } \text { ROI as a rate or } \% \\
\text { - Time frame }=30 \text { years } \\
\text { - Interest rate per year to account for inflation and cost of living } \\
\text { increases }=4.3 \% \\
\text { - Student loan interest rate is not reported } \\
\text { - } \text { ROI= (gains over } 30 \text { years - the cost of the degree) / cost of } \\
\text { the degree }\end{array}$ \\
\hline $\begin{array}{l}\text { Bankrate } \\
\text { Kahn (2013) }\end{array}$ & $\begin{array}{l}\text { - Cost: tuition, fees, and room and board of a four-year, in-state, public school with no scholarships } \\
\text { - Education cost data from the National Center for Education Statistics } \\
\text { - Occupational data from the Bureau of Labor Statistics }\end{array}$ & $\begin{array}{l}\text { - ROI as years } \\
\text { - Time frame is the unknown that is calculated } \\
\text { - The student loan interest }=6 \% \\
\text { - Salary interest rate per year to account for inflation and cost of } \\
\text { living is not reported } \\
\text { - ROI=Years needed to repay education investment with } 10 \% \text { of } \\
\text { median salary used for paying cost of education }\end{array}$ \\
\hline
\end{tabular}


Table 2. The advantages and disadvantages of different sources calculating ROI on investment in education

\begin{tabular}{|c|c|c|}
\hline Source & Advantages & Disadvantages \\
\hline PayScale & $\begin{array}{l}\text { - Uses the current dollar amount on the } \\
\text { median salary data (for both college } \\
\text { graduate and the high school graduate } \\
\text { levels) to account for interest and } \\
\text { inflation, so earnings figures reflect } \\
\text { current dollars (Lavelle, 2012a, 2012b; } \\
\text { Stainburn, 2013). } \\
\text { - Reflects more realistic-median } \\
\text { midcareer salaries, } 10 \text { years plus instead } \\
\text { of entry-level and low pay salaries } \\
\text { (Stainburn, 2013). } \\
\text { - Several different ROIs for different } \\
\text { groups are calculated based on } \\
\text { residence, family and financial } \\
\text { situation. } \\
\text { - Accounts for financial losses for not } \\
\text { entering job market after high school. } \\
\text { - Factors in inflation on salary. }\end{array}$ & $\begin{array}{l}\text { - Missing information: } \\
\text { - High school graduate median pay } \\
\text { - Validity \& Reliability: } \\
\text { • Reflects ROI at the college level and does not } \\
\text { account variations among specific programs or } \\
\text { majors (Lavelle, 2012a, 2012b; Stainburn, 2013). } \\
\text { - Results are suspected to reflect bias towards } \\
\text { certain individuals such as younger and white } \\
\text { collars since data are self-reported by individuals } \\
\text { who use its online pay tools and self-employed, } \\
\text { project-based, contract employees and graduates } \\
\text { with advanced degrees were excluded (Stainburn, } \\
\text { 2013). } \\
\text { - Methodology has incurred changes, thus not } \\
\text { uniform across years, which makes ROI of } \\
\text { different years not comparable (Lavelle, 2012a, } \\
\text { 2012b). } \\
\text { - Assumes that all high school graduates would } \\
\text { acquire a job after graduation. } \\
\text { - Overlooks additional income from internship and } \\
\text { outside work. }\end{array}$ \\
\hline $\begin{array}{l}\text { College } \\
\text { Reality } \\
\text { Check }\end{array}$ & $\begin{array}{l}\text { - Same as above: the salary data come } \\
\text { from PayScale, the same advantages } \\
\text { listed for PayScale apply. }\end{array}$ & $\begin{array}{l}\text { - Time frame is relatively short (10 years). } \\
\text { - Missing information: } \\
\text { - Early career earnings (Same as PayScale) } \\
\text { - Salary inflation rate } \\
\text { - Validity \& Reliability: Same disadvantages listed for } \\
\text { PayScale above apply. }\end{array}$ \\
\hline Salary.com & $\begin{array}{l}\text { - Uses the general ROI formula, more } \\
\text { simplistic and standard. }\end{array}$ & - Missing information: student loan interest rate \\
\hline $\begin{array}{l}\text { Bankrate } \\
\text { Kahn } \\
(2013)\end{array}$ & - ROI as years is easy to comprehend. & $\begin{array}{l}\text { - Missing information: salary inflation rate } \\
\text { - Validity \& Reliability: Same as PayScale, reflects ROI } \\
\text { at the college level and does not account variations } \\
\text { among specific programs or majors. }\end{array}$ \\
\hline
\end{tabular}


Table 3. Education and salary information of respondents

\begin{tabular}{|c|c|c|c|c|c|}
\hline & $\mathbf{N}$ & Min. & Max. & Mean & Std. Dev. \\
\hline Year graduated from Rosen College & 500 & 1986 & 2014 & 2007 & 5.7 \\
\hline $\begin{array}{l}\text { \# of years to complete undergraduate } \\
\text { education }\end{array}$ & 497 & 2 & 20 & 4.23 & 1.4 \\
\hline $\begin{array}{l}\text { Total cost of undergraduate education } \\
\text { (tuition, fees, books, incidentals etc.) }\end{array}$ & 375 & 2000 & $\$ 355,000$ & $\begin{array}{l}\$ 44,257 \\
(\text { median }=\$ 35 \mathrm{~K})\end{array}$ & $\$ 34,493$ \\
\hline $\begin{array}{l}\text { Years of work in tourism or hospitality } \\
\text { organizations }\end{array}$ & 330 & 0 & 40 & 10 & 6.6 \\
\hline Current annual salary & 412 & 4000 & $\$ 350,000$ & $\begin{array}{l}\$ 53,291 \\
\text { (median=43K) }\end{array}$ & $\$ 40,821$ \\
\hline $\begin{array}{l}\text { GRADYEAR (calculated by subtracting } \\
\text { graduation year from } 2014\end{array}$ & 500 & 0 & 28 & 7.5 & 5.7 \\
\hline
\end{tabular}


Table 4. ROI calculation formulas, assumptions and results

\begin{tabular}{|c|c|c|}
\hline ROI Method & Formula and Assumptions & ROI (\$, years, rate or \%) \\
\hline $\begin{array}{l}\text { PayScale } \\
\text { Method }\end{array}$ & $\begin{array}{l}\text { - Time frame }=20 \text { years } \\
\text { - The salary inflation rate }=3.3 \% \\
\text { - Median salary }=\$ 43 \mathrm{~K} \\
\text { - Median education cost }=\$ 35 \mathrm{~K} \\
\text { - } 24 \text { years earnings of high school graduate with median income-30K with 3.3\% } \\
\text { interest annually }=\$ 1,072,505 \\
\text { - } 20 \text { years earnings with } 3.3 \% \text { interest rate }=\$ 1,184,795 \\
\text { - education cost in } 20 \text { years with compound interest of } 6.8 \%=\$ 130,465 \\
\text { - ROI [ } 20 \text {-Year Return on Investment ( } 2013 \text { Dollars)] = Earnings Differential (the } \\
\text { difference between the } 20 \text { Year Median Pay for a } 2013 \text { Bachelor's Graduate and } \\
24-26 \text { Year Median Pay for a High School Graduate) - Total Cost for a Graduate } \\
\text { in } 2013 \\
\text { - No weighting is done since the data is specific to one college. } \\
\text { Additional assumptions (due to lack of information from the source) } \\
\text { - High school graduate median pay is unknown (assumed } \$ 30 \mathrm{~K} \text { as reported by U.S. } \\
\text { - Separtment of Education, National Center for Education Statistics, } 2013 \text { ) } \\
\text { - Check) } \\
\text { - Loans were amortized to calculate ROI with amortization. The grace period of the } \\
\text { student loan was set at } 49 \text { months, meaning that the student would start with } \\
\text { amortizing his loan at month } 50 \text {. Loan after } 50 \text { months = } \$ 43,230.21\end{array}$ & $\begin{array}{l}\text { - Without student loans }= \\
\$ 77,290 \\
\text { - With student loans }= \\
-\$ 18,175 \\
\text { - With student loans, if loans } \\
\text { amortized }=\$ 33,101\end{array}$ \\
\hline $\begin{array}{l}\text { College } \\
\text { Reality } \\
\text { Check } \\
\text { Method }\end{array}$ & $\begin{array}{l}\text { - Time frame }=10 \text { years } \\
\text { - Student loan interest rate }=6.8 \% \\
\text { - Median salary= } \$ 43 \mathrm{~K} \\
\text { - Median education cost }=\$ 35 \mathrm{~K} \\
\text { - } 14 \text { years earnings of high school graduate with median income }-30 \mathrm{~K} \text { with } 3.3 \% \\
\text { interest annually }=\$ 523,136 \\
\text { - } 10 \text { years earnings with } 3.3 \% \text { interest rate }=\$ 499,812 \\
\text { - } \text { education cost in } 10 \text { years with compound interest of } 6.8 \%=\$ 67,574 \\
\text { - ROI = Median earnings over } 10 \text { years - (Average net price + Early-career } \\
\text { earnings over } 10 \text { years) } \\
\text { Additional assumptions (due to lack of information from the source) } \\
\text { - Early career earnings (high school graduate) median pay is unknown (assumed } \\
\text { } \$ 30 \mathrm{~K} \text { as reported by U.S. Department of Education, National Center for } \\
\text { Education Statistics, } 2013 \text { ) } \\
\text { - Inflation rate for salary is unknown (assumed } 3.3 \% \text {, the same as PayScale) } \\
\text { - Loans were amortized to calculate ROI with amortization. The grace period of the } \\
\text { student loan was set at } 49 \text { months, meaning that the student would start with } \\
\text { amortizing his loan at month } 50 \text {. Loan after } 50 \text { months = } \$ 43,230.21 \\
\end{array}$ & $\begin{array}{l}\text { - Without student loans = } \\
-\$ 58,324 \\
\text { - With student loans }= \\
-\$ 90,898 \\
\text { - With student loans, if loans } \\
\text { amortized }=-\$ 83,023\end{array}$ \\
\hline $\begin{array}{l}\text { Salary.com } \\
\text { Method }\end{array}$ & $\begin{array}{l}\text { - Time frame }=30 \text { years } \\
\text { - Interest rate per year to account for inflation and cost of living increases }=4.3 \% \\
\text { - Median salary }=\$ 43 \mathrm{~K} \\
\text { - Median education cost }=\$ 35 \mathrm{~K} \\
\text { - } 30 \text { years earnings with } 4.3 \% \text { interest }=\$ 2,536,138 \\
\text { - } \mathrm{ROI}=\text { (gains over } 30 \text { years - the cost of the degree } \text { )/ cost of the degree } \\
\text { Additional assumptions (due to lack of information from the source) } \\
\text { - Student loan interest rate is unknown (assumed } 6.8 \% \text {, the same as College Reality } \\
\text { Check) } \\
\text { - Loans were amortized to calculate ROI with amortization. The grace period of the } \\
\text { student loan was set at } 49 \text { months, meaning that the student would start with } \\
\text { amortizing his loan at month } 50 \text {. Loan after } 50 \text { months }=\$ 43,230.21\end{array}$ & $\begin{array}{l}\text { - Without student loans = } \\
71.5 \% \\
\text { - With student loans = } \\
9.1 \% \\
\text { - With student loans, if } \\
\text { loans amortized = 24\% }\end{array}$ \\
\hline $\begin{array}{l}\text { Bankrate } \\
\text { Method }\end{array}$ & $\begin{array}{l}\text { - } \text { Time frame }=\text { unknown } \\
\text { - } \text { The student loan interest }=6 \% \\
\text { - } \text { Median salary }=\$ 43 \mathrm{~K} \\
\text { - } \text { Median education cost }=\$ 35 \mathrm{~K} \\
\text { - } \text { ROI=Years needed to repay education investment with } 10 \% \text { of median salary } \\
\text { used for paying cost of education }\end{array}$ & $\begin{array}{l}\text { ROI as years to pay back } \\
\text { education cost }\end{array}$ \\
\hline
\end{tabular}


- Without student loans (n=years)

Years $(n)=\underline{\text { Median education cost }}$

Median salary*0.1

- With student loans (n=years)

Years $(\mathrm{n})=$ Median education $\operatorname{cost}^{*}(1.06)^{\mathrm{n}}$

Median salary*0.1

Additional assumptions (due to lack of information from the source)

- Salary is fixed at $\$ 43 \mathrm{~K}$ for some calculations and inflated at 3.3\% per year for some other calculations.

- Loans were amortized to calculate ROI with amortization. The grace period of the student loan was set at 49 months, meaning that the student would start with amortizing the loan at month 50. Loan after 50 months $=\$ 43,230.21$.
- Without student loans and salary increasing $3.3 \%$ annually $=7.1$ years

- Without student loans and fixed salary $=8.1$ years

- With student loans and increasing payments from salary increasing 3.3\% annually = 13.6 years

- With student loans, amortized with fixed amount of payments (\$350.79) per month $=16$ years 
Table 5. Rosen Method of ROI with segmented amortization, assumptions and results

\section{Rosen Method of ROI as years to pay back education cost}

\section{Formula and Assumptions}

- Time frame = unknown

- The student loan interest $=6.8 \%$ (same as PayScale)

- Median salary $=\$ 43 \mathrm{~K}$

- Median education cost $=\$ 35 \mathrm{~K}$

- ROI=Years needed to repay education investment with X\% of median salary used for paying cost of education

- $\mathrm{x}=10 \%$, $\$ 358.33$ per month

- $x=20 \%$, $\$ 716.67$ per month

- $x=30 \% \$ 1,075.00$ per month

- Without student loans (n=years)

Years $=$ Median education cost

Median salary*( 0.1 or 0.2 or 0.3$)$

- With student loans (n=years)

Years(n) $=$ Median education $\operatorname{cost}^{*}(1.068)^{\mathrm{n}}$

Median salary* ( 0.1 or 0.2 or 0.3 )

- Salary is fixed at $\$ 43 \mathrm{~K}$ for some calculations and inflated at 3.3\% per year for some other calculations.

- Loans are amortized to calculate ROI with amortization. The grace period of the student loan was set at 49 months, meaning that the student would start with amortizing his loan at month 50. Loan after 50 months $=\$ 43,230.21$.

- Education debt for those students who make additional money through internship $=\$ 24 \mathrm{~K}$

- A median income from mandatory 39-42 weeks internship calculated from a survey of Rosen College students $=\$ 11 \mathrm{~K}$

- This income is assumed to pay some of the education cost and subtracted from $\$ 35 \mathrm{~K}$.

- Education debt for those students who make additional money through internship and outside work $=\$ 11 \mathrm{~K}$

- A median income from mandatory 39-42 weeks internship calculated from a survey of Rosen College students $=\$ 11 \mathrm{~K}$

- A median income of additional income besides internship calculated from a survey of Rosen College students $=\$ 13 \mathrm{~K}$

- Both internship and outside work income is assumed to pay some of the education cost and subtracted from $\$ 35 \mathrm{~K}$.

\begin{tabular}{|c|c|c|c|c|}
\hline Education Finance & Payment Plans & \multicolumn{3}{|c|}{ Additional Income Situations } \\
\hline $\begin{array}{l}\text { With or without } \\
\text { student loans }\end{array}$ & $10 \% / 20 \% / 30 \%$ & $\begin{array}{c}\begin{array}{c}\text { With no } \\
\text { additional } \\
\text { income }\end{array} \\
\text { (Education } \\
\text { Debt=\$35K) }\end{array}$ & $\begin{array}{c}\text { With } \\
\text { additional } \\
\text { income from } \\
\text { Internship } \\
\text { (Education } \\
\text { Debt= \$24K) }\end{array}$ & $\begin{array}{c}\text { With additional } \\
\text { income from } \\
\text { internship and outside } \\
\text { work } \\
\text { (Education Debt }=\$ 11 \mathrm{~K} \text { ) }\end{array}$ \\
\hline \multirow{3}{*}{$\begin{array}{l}\text { Without student loans } \\
\text { and salary increasing } \\
3.3 \% \text { annually }\end{array}$} & At 10\% salary cap & 7.1 years & 5.1 years & 2.5 years \\
\hline & At $20 \%$ salary cap & 3.6 years & 2.6 years & 1.3 years \\
\hline & At $30 \%$ salary cap & 2. 3 years & 1.3 years & 6.5 months \\
\hline \multirow{3}{*}{$\begin{array}{l}\text { Without student loans } \\
\text { and fixed salary }\end{array}$} & At $10 \%$ salary cap & 8.1 years & 6.9 years & 3.1 years \\
\hline & At $20 \%$ salary cap & 4 years & 3.4 years & 1.6 years \\
\hline & At 30\% salary cap & 2.7 years & 2.3 years & 1 year \\
\hline \multirow{3}{*}{$\begin{array}{l}\text { With student loans } \\
\text { amortized with fixed } \\
\text { amount of payments }\end{array}$} & At $10 \%$ salary cap & 17 years & 9.3 years & 3.6 years \\
\hline & At $20 \%$ salary cap & 6.2 years & 3.9 years & 1.7 years \\
\hline & At $30 \%$ salary cap & 3.8 years & 2.5 years & 1.1 years \\
\hline
\end{tabular}

